\title{
Electrochemical and Stress Corrosion Cracking Behavior of Alpha-Al Bronze in Sulfide-Polluted Salt Water: Effect of Environmentally-Friendly Additives
}

\author{
Elsayed A. Ashour ${ }^{1 *}$, Lobna A. Khorshed ${ }^{1}$, Gehan I. Youssef ${ }^{1}$, Hossam M. Zakria ${ }^{2}$, Tarek A. Khalifa ${ }^{2}$ \\ ${ }^{1}$ Electrochemistry Laboratory, Physical Chemistry Department, National Research Centre, Dokki, Cairo, Egypt; ${ }^{2}$ Mechanical Engi- \\ neering Department, Faculty of Engineering at Shoubra, Benha University, Cairo, Egypt. \\ Email: easshour@yahoo.com
}

Received October 22 ${ }^{\text {nd }}, 2013$; revised November $27^{\text {th }}, 2013$; accepted December $19^{\text {th }}, 2013$

Copyright (C) 2014 Elsayed A. Ashour et al. This is an open access article distributed under the Creative Commons Attribution License, which permits unrestricted use, distribution, and reproduction in any medium, provided the original work is properly cited. In accordance of the Creative Commons Attribution License all Copyrights @ 2014 are reserved for SCIRP and the owner of the intellectual property Elsayed A. Ashour et al. All Copyright (C 2014 are guarded by law and by SCIRP as a guardian.

\section{ABSTRACT}

The stress corrosion cracking (SCC) behavior of $\alpha$ - $\mathrm{Al}$ bronze alloy $\left(\mathrm{Cu}_{7} \mathrm{Al}\right)$ was investigated in $3.5 \% \mathrm{NaCl}$ solution in the absence and in the presence of different concentrations of $\mathrm{Na}_{2} \mathrm{~S}$ under open circuit potentials using the constant slow strain rate technique. Also, the addition of different concentrations of cysteine (cys), and alanine (ala) to the test solution, as corrosion inhibitors, was studied. Increasing the sulfide ions concentration in polluted salt water resulted in a reduction in the maximum stress $\left(\sigma_{\max }\right)$ and an increase in the susceptibility of $\alpha$-Al bronze towards SCC. The addition of ala and cys to the test electrolyte increased the time to failure by changing the mode of failure from brittle transgranular cracking to ductile failure. Electrochemical tests were performed to assist the interpretation of the SCC data. Electrochemical impedance spectroscopy (EIS) was used to investigate the mechanism of corrosion inhibition. The results support film rupture and anodic dissolution at slip steps as the operating mechanism of the SCC process. Therefore, cys and ala can be considered as potential environmentally-friendly corrosion inhibitors for the SCC of $\alpha$-Al bronze in $3.5 \% \mathrm{NaCl}$ solution containing sulfide ions.

\section{KEYWORDS}

Bronze; Sulfide; Corrosion; SCC; Inhibitor; Amino Acids

\section{Introduction}

Copper-base alloys have a long history of service in marine environments. Aluminum bronzes contain copper as the major component and aluminum as a minor component. They have good strength [1-6] and superior resistance to cavitation erosion and impingement attack [7]. Al-bronzes have been used in various sea water applications [1,8-10], the manufacturing of acid handling equipment, and dental restoration [2]. Small quantities of Fe, $\mathrm{Ni}$, or Ag may be added to Al-bronzes to improve their corrosion resistance and mechanical properties [1-4]. The corrosion resistance was attributed to the formation of a thin film of $\mathrm{Al}_{2} \mathrm{O}_{3}$, which heals rapidly when dam-

*Corresponding author. aged [11-13]. The corrosion resistance of Al-bronze increases with increasing the aluminum content up to about $9.6 \%$, which represents the limit of the $\infty$-phase [14]. Beyond that limit, the two-phase alloys undergo severe corrosion and loss of ductility, which had been attributed to selective loss of aluminum [10,15-17] i.e. dealuminification. In this regard, the electrochemical and stress corrosion cracking (SCC) behavior of Al-bronzes has been reported in marine and desalination environments [18-20] and in 3.4\% NaCl solutions [13].

Various pollutants, such as nitrite ions [18], are often introduced in the work environments, which might have a delirious effect on the workability of such alloys [19]. More seriously, the presence of sulfide ions in seawater, from seaweed, sulfide reduced bacteria, or industrial 
waste discharge, is known to promote aqueous corrosion of copper and its alloys with greater damage than that caused by $\mathrm{Cl}^{-}$ions $[19,20]$. However, it seems that the study of the effect of such pollutant on the stability of Al-bronzes is very rare [18].

Therefore, the aim of the present work is to study the propensity of $\infty$-Al bronze to stress corrosion cracking in sulfide-polluted salt water. A complete set of electrochemical characterization techniques have also been used to understand the electrochemical behavior of the alloy in such environments. Moreover, cysteine (cys) and alanine (ala) have been investigated as positional environmentally-friendly additives to suppress the observed damage.

\section{Experimental Procedure}

Tests were performed on commercial $\infty$-Al bronze alloy supplied by Non-ferrous industries company, Helwan, Egypt, with the composition: $7 \% \mathrm{Al}, 0.04 \%$ iron (Fe), $0.01 \%$ nickel $(\mathrm{Ni}), 0.04 \%$ silicon $(\mathrm{Si}), 0.006 \%$ magnesium (Mg), and the balance $\mathrm{Cu}$. The mechanical properties are: Ultimate tensile stress (UTS) of $150 \mathrm{~kg} / \mathrm{mm}^{2}$, yield stress (YS) of $48 \mathrm{~kg} / \mathrm{mm}^{2}$, Hardness is 141 (VHN) and elongation is $6 \%$. A constant slow strain rate machine was used at a constant strain rate of $5.53 \times 10^{-6} \mathrm{~s}^{-1}$. The test cell was in the form of a glass cylinder $(120 \mathrm{~mm}$ in height and $80 \mathrm{~mm}$ in diameter. It was closed at the top and bottom by a rubber stopper through which the ends of the specimens protruded. The specimens were machined to a gauge length of $25 \mathrm{~mm}$ and a diameter of 6 $\mathrm{mm}$.

The samples were polished with 320,600 , and 800 grit silicon carbide $(\mathrm{SiC})$ paper, degreased with acetone, and coated with silicon rubber so that only the gauge length was exposed to the test solution under open circuit potential. The experiments were carried out at $24^{\circ} \mathrm{C} \pm 1^{\circ} \mathrm{C}$ in air, and in aerated $3.5 \% \mathrm{NaCl}$ with different concentrations of $\mathrm{Na}_{2} \mathrm{~S}$ (2, 16, $\left.100 \mathrm{ppm}\right)$. Potentiostatic polarization measurements were performed using a PS6 Meinsperger Potentiostat/Galvanostat (Germany). A three electrode electrochemical cell made of pyrex glass, with a saturated calomel electrode (SCE) as a reference electrode, a platinum foil as a counter electrode, and $\alpha$-Al bronze specimen as the working electrode, was used. Electrochemical impedance spectroscopy (EIS) was carried out with a potentiostat/galvanostat (Gamry PCI 300/ 4) and a personal computer with EIS 300 software for calculations at $E_{\text {opc }}$ after 30 min. of immersion in solution. After the determination of steady - state current at a given potential, sine wave $(10 \mathrm{mV})$ peak to peak, at frequencies between $5 \times 10^{3} \mathrm{~Hz}$ and $0.02 \mathrm{~Hz}$ were superimposed on the rest potential. The impedance diagrams are given in the Nyquist and Bode representation. Cracking specimens were removed from the solution after fail- ure, cut $1 \mathrm{~cm}$ beyond the crack tip and subjected to scanning electron microscopy (SEM) using JEOL, JXA-840 A Electron Probe Microanalyzer, Japan.

\section{Results and Discussion}

\subsection{Stress Corrosion Cracking (SCC) Behavior of $\alpha$-Al Bronze}

\subsubsection{Effect of Sulfide Ions}

Stress-strain curves were measured in $3.5 \% \mathrm{NaCl}$ in the presence and absence of different concentrations of sodium sulfide under open circuit conditions. Measurements were also performed in air for comparison. The results are shown in Figure 1(a) and summarized in Table 1 in terms of the maximum stress $(\sigma)$, time to failure $\left(T_{f}\right)$, stress ratio $(\tau)$, time to failure ratio $(r)$, susceptibility to SCC $(S)$ and mode of failure for samples tested under the various conditions.

The curves show the same conventional shape usually seen for other alloys and are characterized by an increase in strain with increasing stress until the yield stress point $\left(\sigma_{\max }\right)$ is reached, followed by a slight gradual increase in the form of plateau until it reaches a maximum, after which the strain begins to decline to reach the point of failure. The susceptibility to stress corrosion cracking was measured by the ratios of both the time to failure $(\tau)$ and the maximum stress $(r)$, where the maximum stress ratio is defined as [21]:

$$
r=\frac{\sigma_{\max }(\text { sol })}{\sigma_{\max }(\text { air })}
$$

and the ratio of time to failure as:

$$
\tau=\frac{t_{f}(\text { sol })}{t_{f}(\text { air })}
$$

The values of $r$ and $\tau$ and the metallographic appearance of the fracture surfaces are useful criteria for assessing susceptibility to SCC. In a previous report [21] both $r$ and $\tau$ were combined in a quantitative phenomenological expression for the susceptibility $(S)$ to SCC, given by:

$$
S=[(1-r)(1-\tau)]^{1 / 2}
$$

Figure 1(a) shows the stress-strain curves of $\infty$-Al bronze in $3.5 \% \mathrm{NaCl}$ with different concentrations of sulfide ions (2.16 and $100 \mathrm{ppm})$ at a strain rate of $5.53 \times$ $10^{-6} \mathrm{~s}^{-1}$ under open-circuit potential (OCP). The increase of sulfide ion to $100 \mathrm{ppm}$ led to a decrease in the maximum stress. Note the similarity in behavior for the samples tested in air and in sulfide-free $\mathrm{NaCl}$ electrolytes. However, upon the addition of sulfide ions, the propensity of $\alpha$-Al-bronze to SCC was found to depend on the 


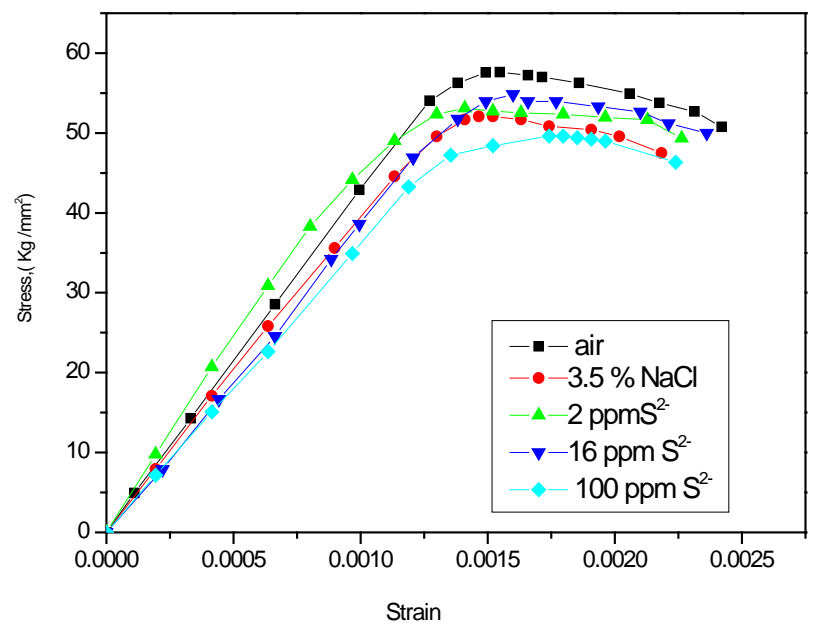

(a)

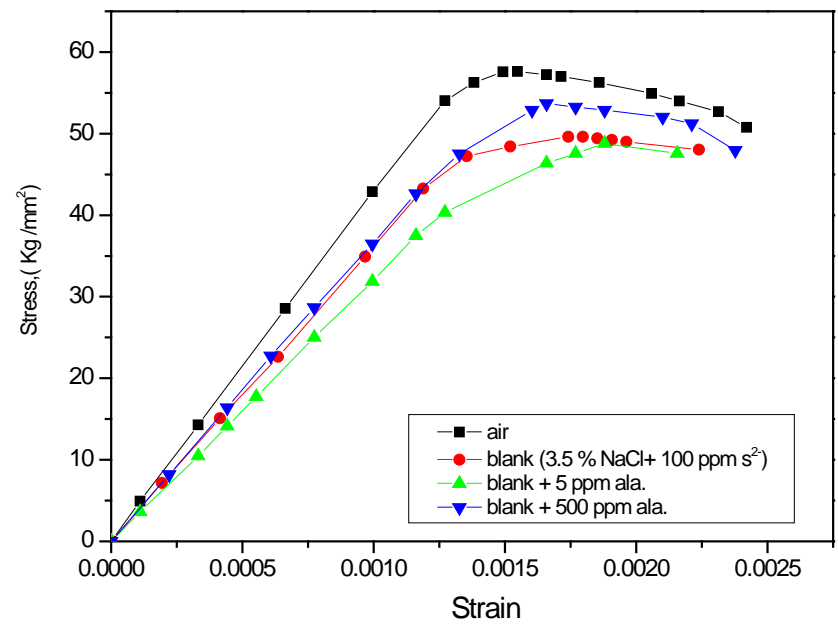

(b)

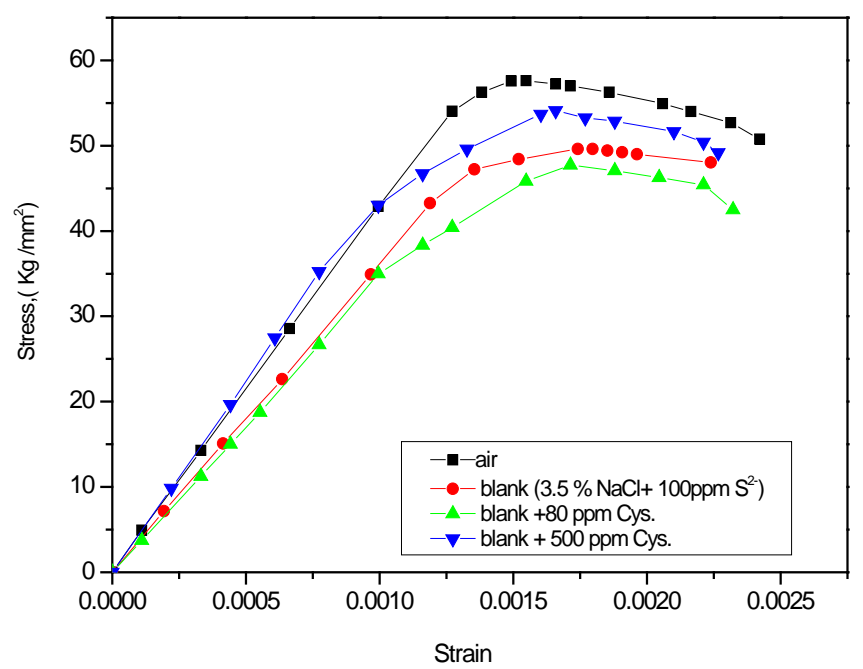

(c)

Figure 1. Stress-strain curves of Al-bronze at strain rate $5.53 \times 10^{-6} \mathrm{~s}^{-1}$ in air and in $3.5 \% \mathrm{NaCl}$ containing (a) different concentrations of sulfide ions; (b) $100 \mathrm{ppm} \cdot \mathrm{S}^{2-}$ with and without ala; and (c) $100 \mathrm{ppm} \cdot \mathrm{S}^{2-}$ with and without cys.

Table 1. Stress corrosion cracking (SCC) parameters of $\alpha$-Al bronze alloy in $3.5 \% \mathrm{NaCl}$ in the presence of different concentrations of sulfide ion with the different concentration of alanine and cysteine at strain rate of $5.53 \times 10^{-6} \mathrm{~s}^{-1}$.

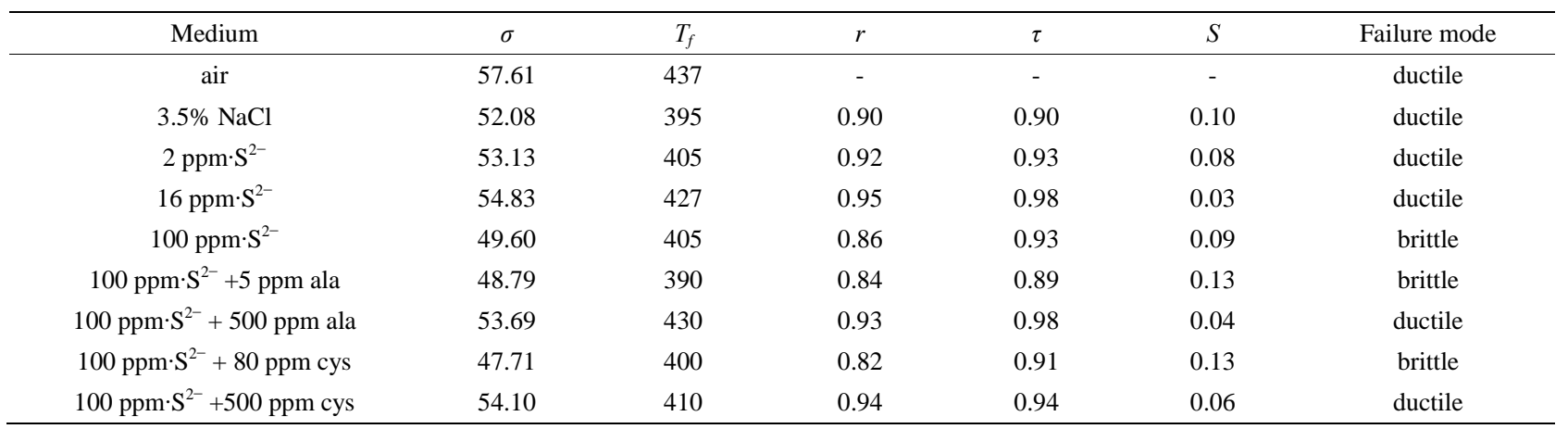

sulfide ion concentration, indicating the promoting effect of sulfide ions on the SCC of $\alpha$-Al bronze. The first step is believed to be an initial adsorption process of the sul- fide species:

$$
\mathrm{HS}_{(a q)}^{-}+\mathrm{Cu}=\mathrm{HS}^{-}: \mathrm{Cu}
$$


where $\mathrm{HS}^{-}: \mathrm{Cu}$ refers to the adsorbed sulfide species on the bare copper surface. This adsorbed species catalyzes the anodic dissolution reaction:

$$
\mathrm{HS}^{-}: \mathrm{Cu}=\mathrm{CuS}+\mathrm{H}^{+}+2 \mathrm{e}^{-}
$$

The resulting sulfide scale ( $\mathrm{CuS}$ and $\mathrm{Cu}_{2} \mathrm{~S}$ ), as well as dissolved sulfide [22,23] catalyzes the partial anodic Equation (5) and cathodic Equation (6) reactions:

$$
\frac{1}{2} \mathrm{O}_{2}+\mathrm{H}_{2} \mathrm{O}+2 \mathrm{e}^{-}=2 \mathrm{OH}^{-}
$$

The overall corrosion reaction is the sum of the two partial reactions Equations (5) and (6), which can be represented as [24]:

$$
\mathrm{HS}^{-}: \mathrm{Cu}+\frac{1}{2} \mathrm{O}_{2}=\mathrm{CuS}+\mathrm{OH}^{-}
$$

Consequently, the rates of reactions 5 - 7 are affected by the sulfide ions that are adsorbed on the alloy surface.

\subsubsection{Effect of Alanine and Cysteine}

The inhibitive effect of two amino acids, alanine (ala) and cysteine (cys), as environmentally-friendly corrosion inhibitors was investigated for the SCC of $\alpha$-Al bronze under the most severe conditions identified above (3.5\% $\mathrm{NaCl}+100 \mathrm{ppm} \cdot \mathrm{S}^{2-}$ at strain rate of $5.53 \times 10^{-6} \mathrm{~s}^{-1}$ ). The results are shown in Figures 2, 3 and Table 2. Figures 1(b) and (c) shows the stress-strain curves obtained for Al-bronze alloy samples tested in air as well as in electrolytes containing $3.5 \% \mathrm{NaCl}$ in the presence of alanine and cysteine inhibitors. It is noted that the addition of alanine $(500 \mathrm{ppm})$ increases the ultimate stress and decreases the susceptibility (S) of the alloy to SCC from 0.09 to 0.04 as listed in Table 1. Similarly, the addition of cysteine increases the ultimate stress and decreases the susceptibility of $\alpha-\mathrm{Al}$ bronze to SCC from 0.09 to 0.06 . This indicates that the addition of ala or cys can be used to improve the resistance of the alloy to SCC in sulfide-polluted salt water.

\subsubsection{Metallographic Characterization}

Figure 2 displays the obtained SEM micrographs of the fractured surfaces obtained in air, in $3.5 \% \mathrm{NaCl}$ and in $3.5 \% \mathrm{NaCl}$ with different concentrations of sulfide ions (2, 16, $100 \mathrm{ppm})$. It can be seen that the mode of failure (Figures 2(a)-(d)) is mainly ductile. However, in the presence of $100 \mathrm{ppm}$ sulfide, the fracture mode was found to be brittle transgranular (Figure 2(e)). Upon the addition of $500 \mathrm{ppm}$ ala or cys to an electrolyte containing $3.5 \% \mathrm{NaCl}+100 \mathrm{ppm} \cdot \mathrm{S}^{2-}$, the mode of failure changes from brittle transgranular to ductile failure (Figures 2(f) and (g)), which is the same mode of failure obtained upon testing the material in air, confirming that amino acids (ala and cys) can act as potential environ- mentally friendly corrosion inhibitors for the SCC of $\alpha$-Al bronze alloy in sulfide-polluted salt water. However, it is important to note that the absence of cracking is not the only factor determining the immunity of the material to SCC (24). The inhibitive effect of ala and cys can be attributed to the adsorption of inhibitor on the alloy surface, which inhibits the anodic dissolution of the alloy by blocking the active sites on the alloy surface and subsequently the SCC.

\subsection{Electrochemical Measurements}

\subsubsection{Potentiostatic Polarization}

Figure 3(a) shows the polarization curves of $\alpha$-Al bronze alloy in $3.5 \% \mathrm{NaCl}$ in the presence of different concentrations of sulfide ion $(2,16,100 \mathrm{ppm})$. Note that the presence of sulfide ions shifts the potential towards more negative potential region and the shift was found to be dependent on the sulfide ion concentration. The sulfide ion results in an increase in the measured anodic current, which can be attributed to the anodic oxidation of the alloy. The current increases abruptly with potential at values near the OCP. At cathodic potentials to $E_{\text {corr }}$ the current is usually a measure of the oxygen reduction reaction in aerated sea water environments.

$$
\mathrm{O}_{2}+2 \mathrm{H}_{2} \mathrm{O}+4 \mathrm{e}^{-} \rightarrow 4 \mathrm{OH}^{-}
$$

However, in the presence of sulfide ions, unstable black cuprous sulfide is formed:

$$
2 \mathrm{Cu}+\mathrm{S}^{2-} \rightarrow \mathrm{Cu}_{2} \mathrm{~S}+2 \mathrm{e}^{-}
$$

According to Tromans et al. [25], $\mathrm{Cu}$ is involved in this reaction:

$$
\begin{gathered}
2 \mathrm{Cu}+\mathrm{H}_{2} \mathrm{O} \rightarrow \mathrm{Cu}_{2} \mathrm{O}+2 \mathrm{H}^{+}+2 \mathrm{e}^{-} \\
\mathrm{Cu}+\mathrm{Cl}^{-} \rightarrow \mathrm{CuCl}+\mathrm{e}^{-}
\end{gathered}
$$

Ashour et al. (12) documented the presence of SCC of a single-phase $\alpha$ - $\mathrm{Al}$ bronze in $3.4 \% \mathrm{NaCl}$ solution and explained the results as a dealloying process occurred through a film of copper chloride (CuCl). The electrochemical behavior of the $\alpha$-Al bronze in $3.4 \% \mathrm{NaCl}$ reveals the formatiom of mostly solid corrosion products at anodic potentials to the free corrosion potential. These are defined as $\mathrm{Cu}_{2} \mathrm{O}$ and $\mathrm{CuCl}$ on the basis of thermodynamics calculation and X-ray diffraction measured on the treated $\alpha$-Al bronze alloy surface (10). This insight is in line with results reported by Neodo et al. [26] confirming that the formation of cuprite $\left(\mathrm{Cu}_{2} \mathrm{O}\right)$ during the copper oxidation in a chloride solution, at $\mathrm{pH} 6.2$, is thermodynamically favoured over $\mathrm{CuCl}$.

Ateya et al. $(10,13)$ as well as Schussler and Exner [27] identified $\mathrm{Al}_{2} \mathrm{O}_{3}$ as an inner adherent layer, acting as a barrier for ionic transport across the corrosion product 


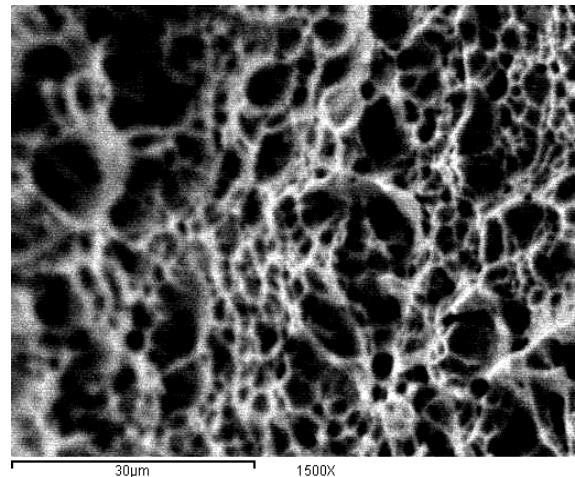

(a)

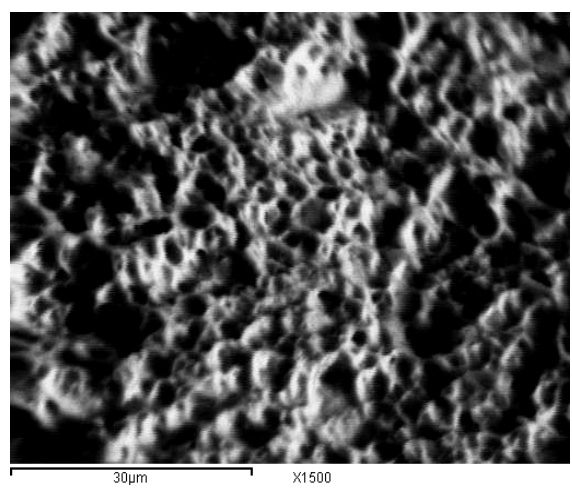

(c)

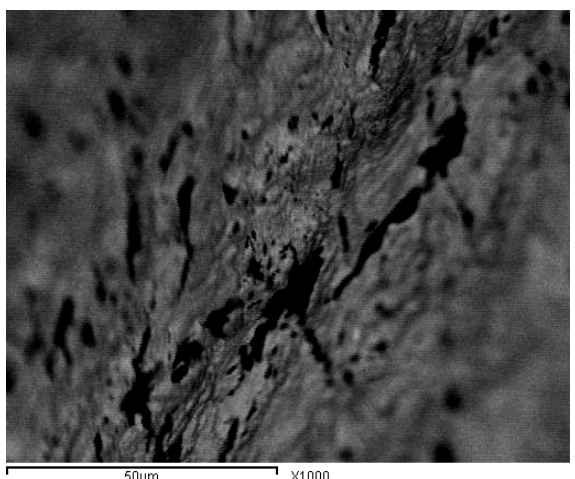

(e)

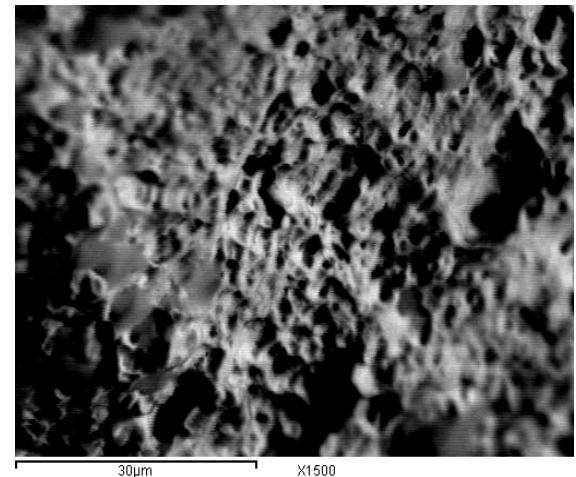

(b)

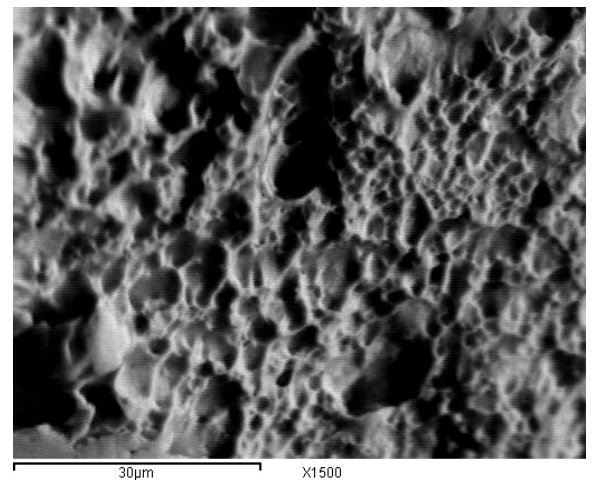

(d)

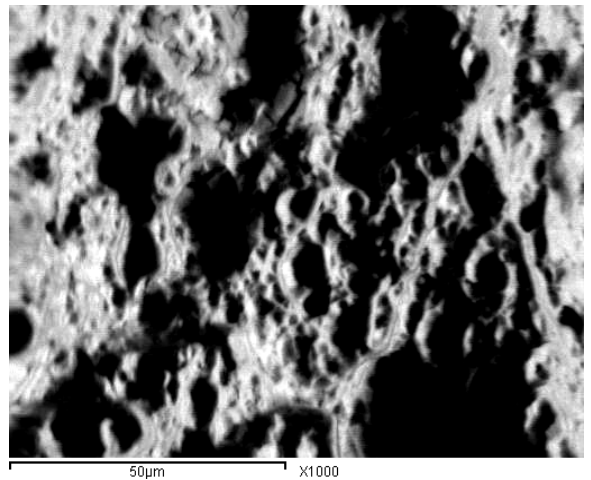

(f)

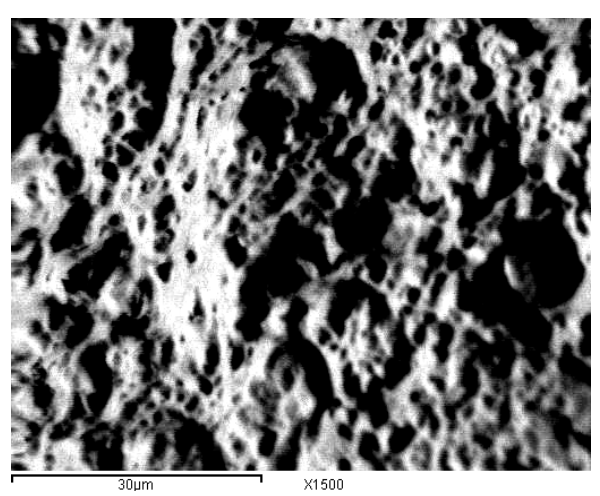

(g)

Figure 2. SEM fractographs of $\alpha$-Al bronze in (a) air, (b) $3.5 \% \mathrm{NaCl}$, (c) $3.5 \% \mathrm{NaCl}+2 \mathrm{ppm} \cdot \mathrm{S}^{2-}$, (d) $3.5 \% \mathrm{NaCl}+16 \mathrm{ppm} \cdot \mathrm{S}^{2-}$ and (c) $3.5 \% \mathrm{NaCl}+100 \mathrm{ppm} \cdot \mathrm{S}^{2-}$, (f) $3.5 \% \mathrm{NaCl}+100 \mathrm{ppm} \cdot \mathrm{S}^{2-}+500 \mathrm{ppm}$ ala, and (g) $3.5 \% \mathrm{NaCl}+100 \mathrm{ppm} \cdot \mathrm{S}^{2-}+500 \mathrm{ppm}$ cys. 


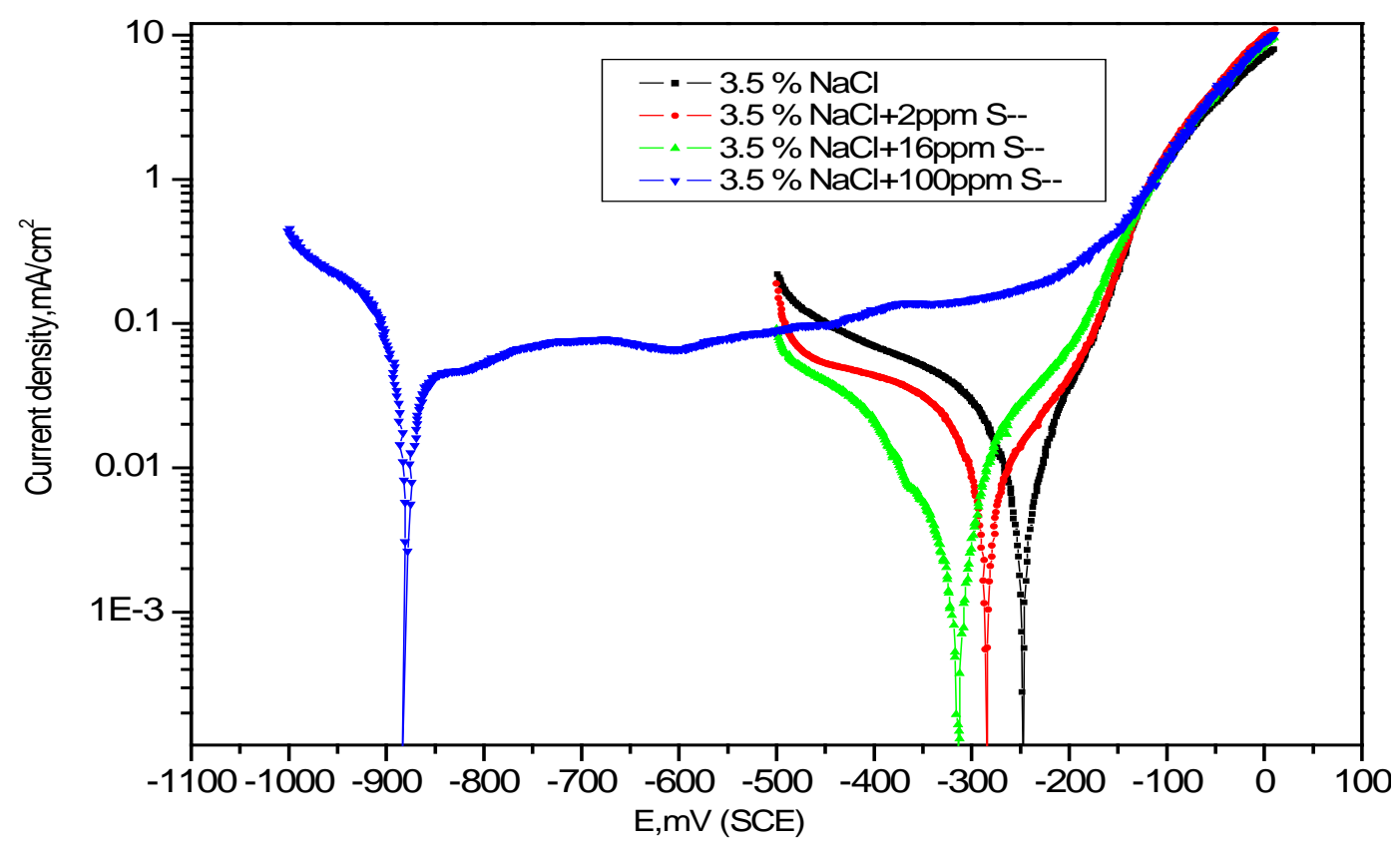

(a)

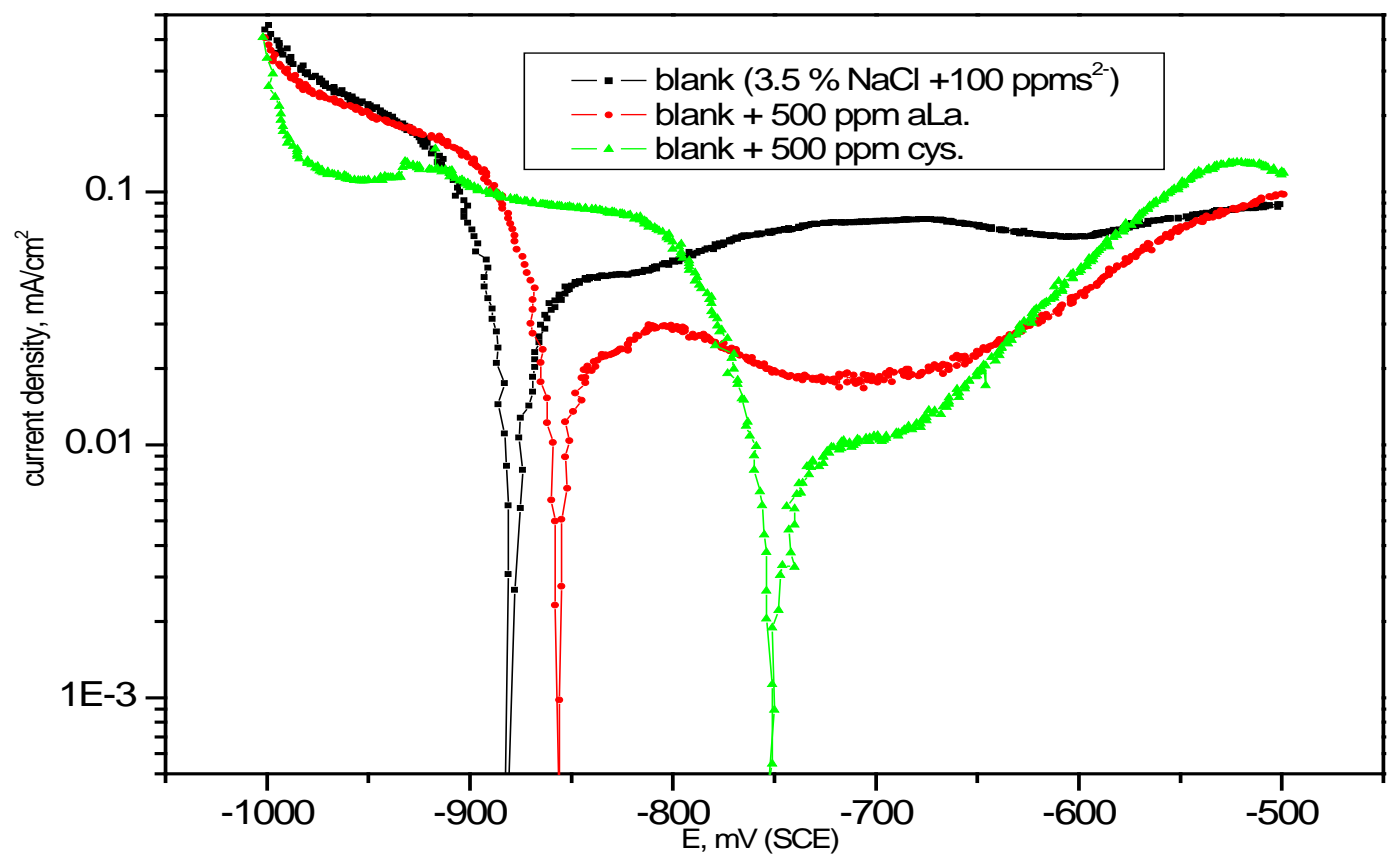

(b)

Figure 3. Polarization curves of $\mathrm{Al}$-bronze in (a) $3.5 \% \mathrm{NaCl}$ with different concentrations of sulfide ions, and (b) $3.5 \% \mathrm{NaCl}$ + $100 \mathrm{ppm} \cdot \mathrm{S}^{2-}$ (blank), blank + $500 \mathrm{ppm}$ ala, blank + 500 ppm cys.

Table 2. The effect of the optimum doses of inhibitors (alanine and cysteine) on the free corrosion potential ( $\left.E_{\text {corr }}\right)$, corrosion current density $\left(\mathrm{I}_{\text {corr }}\right)$, Tafel slopes $\left(\beta_{a}, \beta_{c}\right)$, percentage inhibition efficiency (\%IE),corrosion rate (CR) of $\alpha$-Al bronze alloy in $\left(3.5 \% \mathrm{NaCl}+100 \mathrm{ppm} \cdot \mathrm{S}^{2-}\right)$.

\begin{tabular}{|c|c|c|c|c|c|c|}
\hline Conc., ppm & $\mathbf{I}_{\text {corr. }} \mathbf{m A c m}^{-2}$ & $\mathbf{E}_{\text {corr. }}-\mathbf{m V}$ & $\beta_{c}-$ mVdec. $^{-1}$ & $\beta_{a}$ mVdec. $^{-1}$ & IE\% & Corrosion rate $(\mathrm{CR}) \mathrm{mm} / \mathrm{year}$ \\
\hline blank $\left(3.5 \% \mathrm{NaCl}+100 \mathrm{pm} \cdot \mathrm{S}^{2-}\right)$ & 0.00751 & 885 & 20.3154 & 30.6427 & - & 0.08712 \\
\hline blank +500 ppm ala & 0.00492 & 857 & 17.1083 & 14.6820 & 34.48 & 0.05093 \\
\hline blank + 500 ppm cys & 0.00183 & 750 & 18.2768 & 18.6279 & 75.63 & 0.02126 \\
\hline
\end{tabular}


and $\mathrm{Cu}_{2} \mathrm{O}$ as an outer layer using $\mathrm{X}$-ray diffraction and auger electron spectroscopy (AES) techniques on $\mathrm{Al}$ bronze surfaces in sodium chloride solutions.

$$
2 \mathrm{Al}+3 \mathrm{H}_{2} \mathrm{O} \rightarrow \mathrm{Al}_{2} \mathrm{O}_{3}+6 \mathrm{H}^{+}+6 \mathrm{e}^{-}
$$

The presence of aluminum oxide $\left(\mathrm{Al}_{2} \mathrm{O}_{3}\right)$ often has been postulated to explain the improved corrosion resistance of $\mathrm{Cu}-\mathrm{Al}$ alloys as compared to pure copper. The ability of this oxide to heal rapidly in the work environment is the important criterion for application. Figure 3 (b) shows the polarization curves of the tested alloy in $3.5 \% \mathrm{NaCl}+100 \mathrm{ppm} \cdot \mathrm{S}^{2-}$ (blank) with $500 \mathrm{ppm}$ of alanine (ala) and blank +500 ppm of cysteine (cys). In the presence of inhibitor, the cathodic and anodic curves were shifted toward more-positive potentials, compared to that in the absence of inhibitor. This indicates that the presence of cys and ala species enhances the passivation and retardation of the alloy dissolution due to their adsorption on the alloy surface. The electrochemical corrosion and SCC measurements are in good agreement.

\subsubsection{Electrochemical Impedance Spectroscopy (EIS)}

Electrochemical impedance spectroscopy (EIS) is a powerful, non-destructive electrochemical technique for cha-

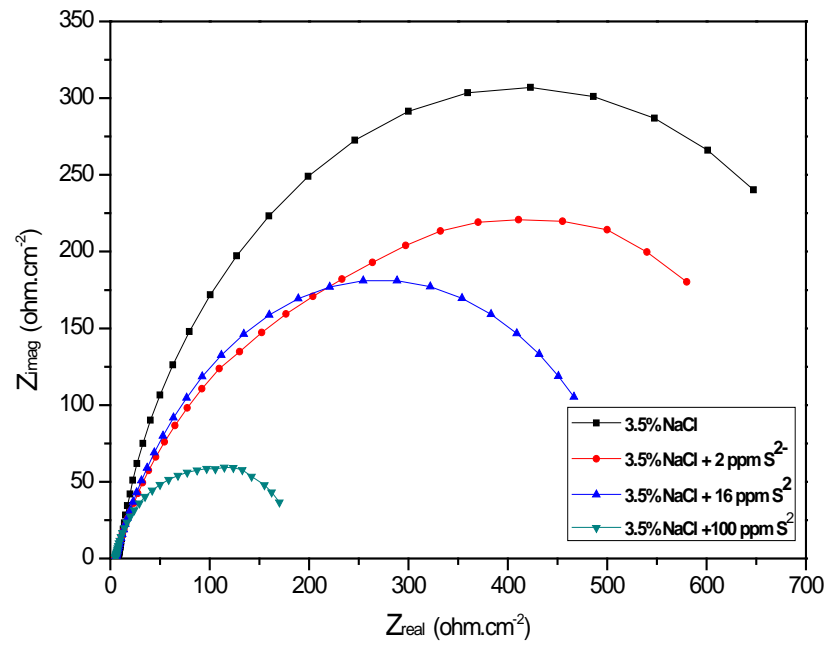

(a) racterizing electrochemical reactions at the metal/electrolyte interface and the formation of corrosion products [28]. Impedance measurements provide information on both the resistive and capacitive behavior of the interface, evaluation on the performance of studied compounds as possible corrosion inhibitor, and investigation of the corrosion inhibition processes [28].

EIS measurements have been carried out for Al-bronze alloy in the absence and presence of different inhibitor concentrations. Figures 4 and 5 illustrate the influence of both ala and cys on the impedance response of Al-bronze alloy in $100 \mathrm{ppm} \cdot \mathrm{S}^{-2}$ at $25^{\circ} \mathrm{C}$. The semicircular appearance of Nyquist plot shows that the charge transfer process takes place during dissolution [29-31]. The simplest fitting is represented by Randles equivalent circuit (Figure 4(c)), which is a parallel combination of the charge-transfer resistance $\left(R_{c t}\right)$ and a constant phase element $\left(C_{d l}\right)$ both in series with the solution resistance $\left(R_{s}\right)$. Table 3 presents the values of $R_{c t}$ and $C_{d l}$ obtained for Al-bronze alloy in the absence and presence of optimum concentration of ala and cys at $25^{\circ} \mathrm{C}$. In all cases, $R_{c t}$ values increase, while those of $\mathrm{C}_{\mathrm{dl}}$ decrease in the presence of ala and cys, possibly due to the adsorption of the inhibitor on the electrode surface [32].

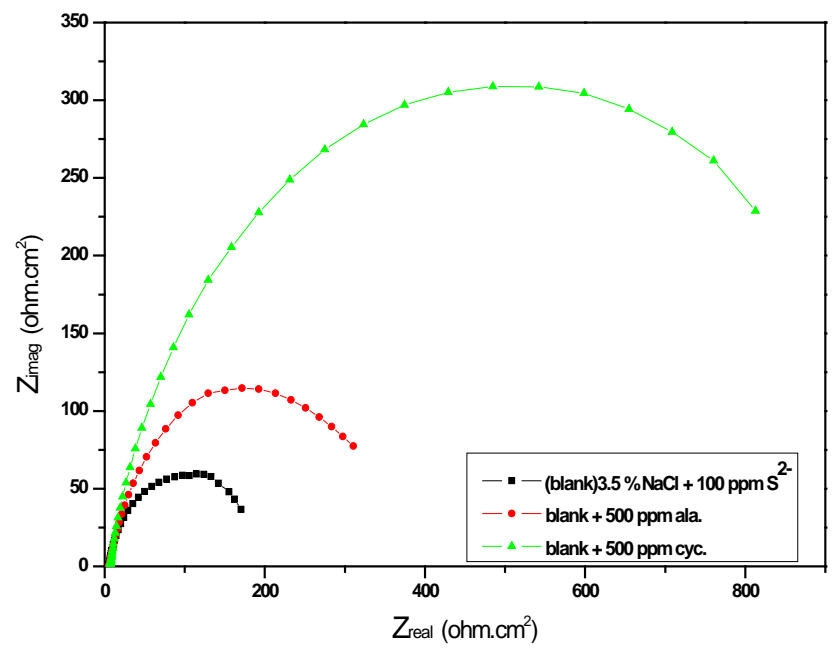

(b)

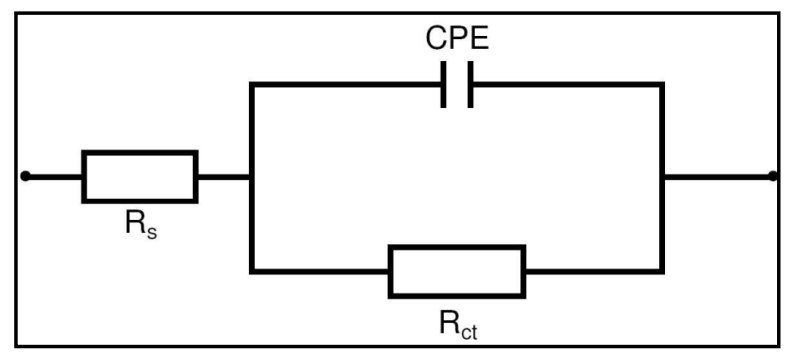

(c)

Figure 4. The Nyquist plots for Al-Bronze alloy in 3.5\% NaCl solutions containing (a) different concentrations of sulfide ions, (b) $100 \mathrm{ppm} \cdot \mathrm{S}^{2-}+500 \mathrm{ppm}$ of ala or cys, and (c) The equivalent circuit model used to fit the impedance data. 


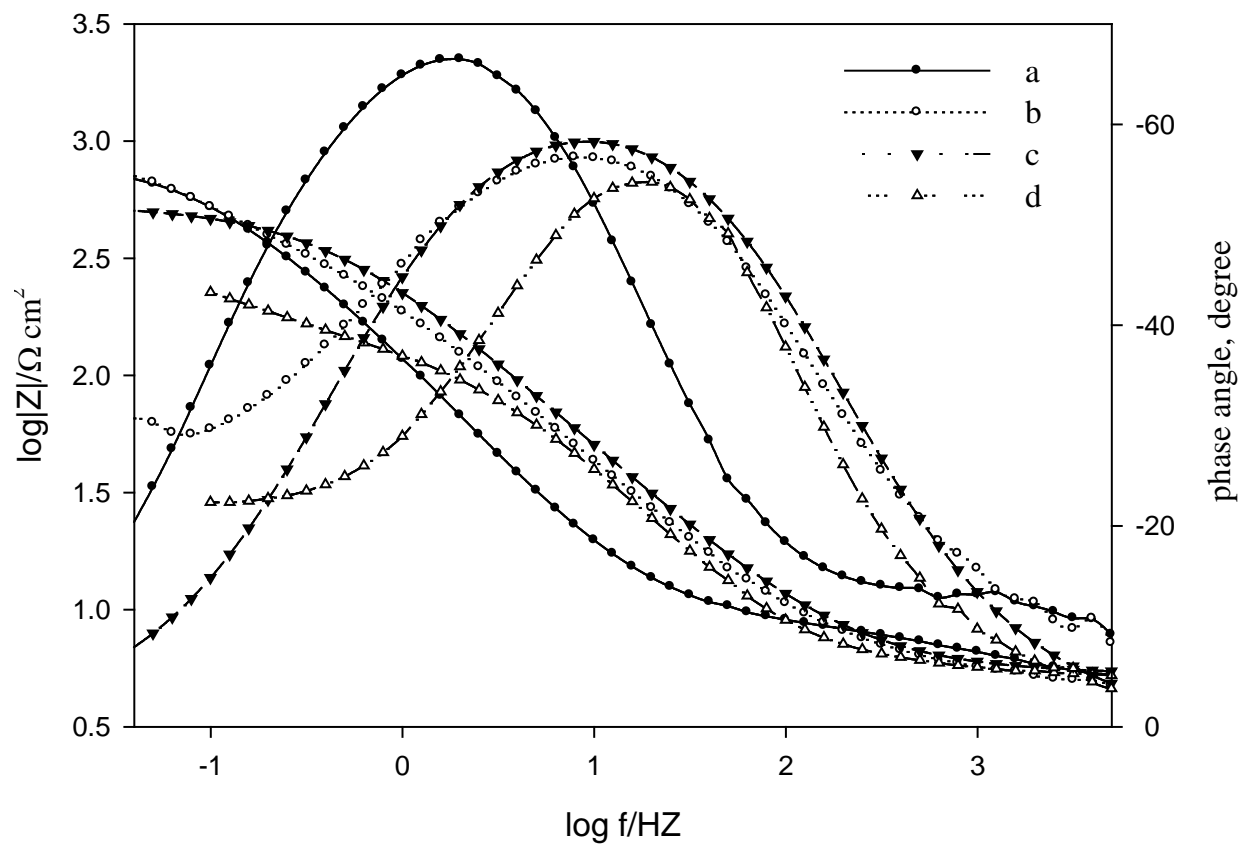

(a)

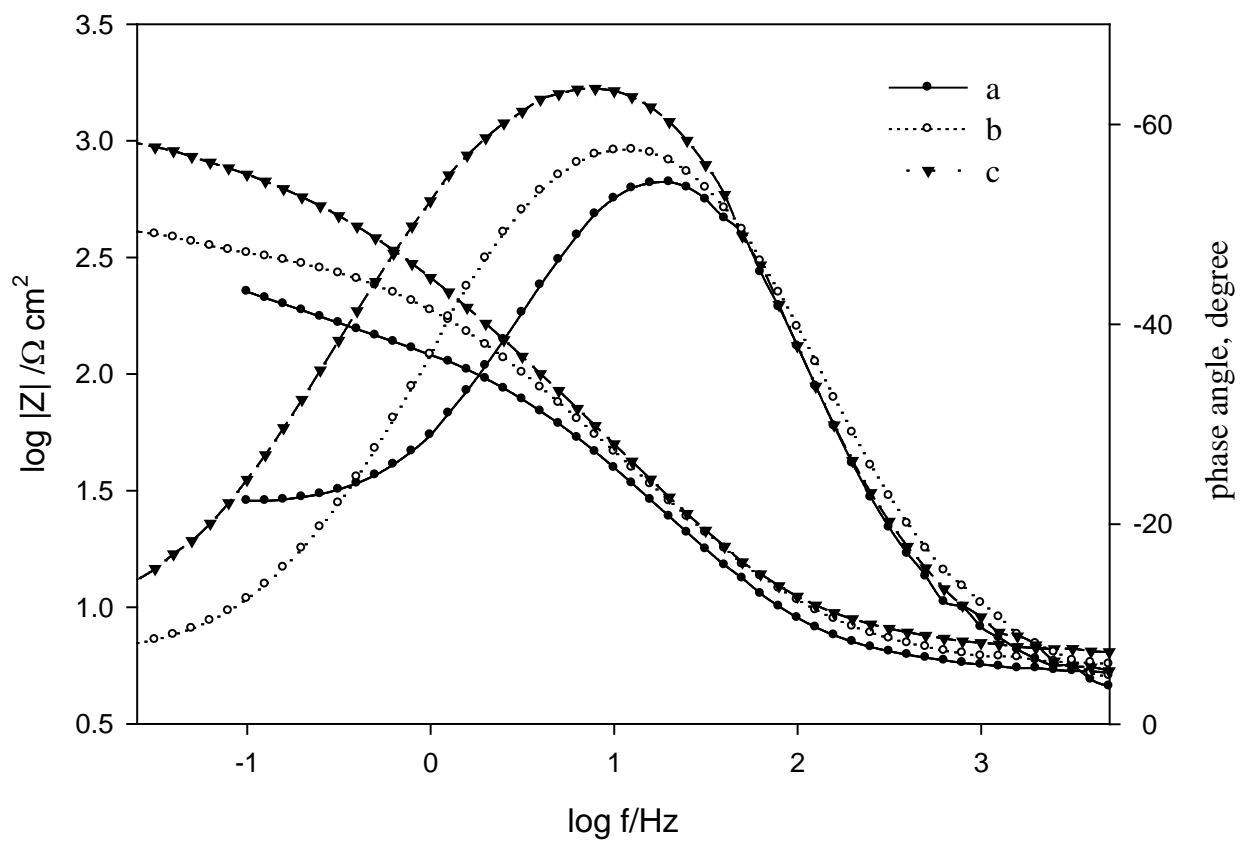

(b)

Figure 5. The Bode plots for Al-bronze alloy in (a) $3.5 \% \mathrm{NaCl}$ in the absence (curve a) and in presence of $2 \mathrm{ppm} \cdot \mathrm{S}^{2-}(\mathrm{curve} b$ ), $16 \mathrm{ppm} \cdot \mathrm{S}^{2-}$ (curve) and $100 \mathrm{ppm} \cdot \mathrm{S}^{2-}$, and (b) $3.5 \% \mathrm{NaCl}+100 \mathrm{~S}^{2-}$ (curve a) and in the presence of $500 \mathrm{ppm}$ ana (curve b), 500 ppm cyst (curve c)

Table 3. Electrochemical kinetic parameters obtained by EIS technique for the corrosion of Al-bronze alloy in $3.5 \% \mathrm{NaCl}+$ $100 \mathrm{ppm} \cdot \mathrm{S}^{2-}$ (blank) and in the presence of $500 \mathrm{ppm}$ alanine, $500 \mathrm{ppm}$ cysteine.

\begin{tabular}{cccccc}
\hline Concentration & $\boldsymbol{R}_{\boldsymbol{s}} \mathbf{O h m} \cdot \mathbf{c m}^{2}$ & $\boldsymbol{R}_{\boldsymbol{c t}} \mathbf{O h m} \cdot \mathbf{c m}^{2}$ & $\boldsymbol{C}_{\boldsymbol{d l}} \boldsymbol{\mu} \mathbf{F} / \mathbf{c m}^{2}$ & $\boldsymbol{n}$ & IE\% \\
\hline Blank( 3.5\% NaCl + 100 ppm·S $\left.{ }^{2-}\right)$ & 5.576 & 204.3 & 402.0 & 0.91 & - \\
blank + 500 ppm ala & 5.576 & 365.8 & 381.2 & 0.94 & 43.0 \\
blank + 500 ppm cys & 6.386 & 962.9 & 317.4 & 0.93 & 78.7 \\
\hline
\end{tabular}


The obtained $R_{c t}$ values were used to calculate the inhibition efficiency $(\eta \%)$ for the different inhibitors as:

$$
\eta(\%)=\left[\left(R_{c t}-R_{c t}^{\prime}\right) / R_{c t}\right] \times 100
$$

where $R_{c t}$ and $R_{c t}^{\prime}$ are the charge transfer resistances for the inhibited and uninhibited solutions, respectively. The obtained $\eta \%$ values are listed in Table 3. Cys was found to act as a better corrosion inhibitor than ala, achieving an inhibition efficiency close to $80 \%$ under the most aggressive conditions used. Cysteine (denoted as R-SH) has more inhibition efficiency than alanine, cys contains-SH group which has strong affinity for copper. Cys can be adsorbed as bidentate ligands, in which surface coordination is taking place through both amino group and the -SH moiety. The corrosion inhibition of cys can be attributed to the adsorption of the - $\mathrm{SH}$ group on $\mathrm{Cu}$ surface blocking more corrosion sites [33,34].

\section{Conclusions}

1) $\alpha$-Al bronze was found to be susceptible to SCC in sulfide-polluted 3.5\% $\mathrm{NaCl}$ solutions.

2) Increasing the sulfide ions concentration leads to a decrease in the maximum stress $\left(\sigma_{\max }\right)$ and changes the mode of the fracture surface from ductile to brittle transgranular.

3) The addition of alanine and cysteine to the test electrolytes reveals the positive effect of amino acids to improve the resistance of the alloy toward SCC in sulfidepolluted salt water, with changing the mode of fracture from brittle transgranular cracking to ductile failure.

4) EIS showed that the presence of ala and cys in the test solution decreases $C_{d l}$ and increases $R_{c t}$.

5) The electrochemical and SCC measurements are in good agreement.

\section{REFERENCES}

[1] R. B. Ross, "Metallic Materials Specification Handbook," 3rd Edition, E. \& F.N. Spon, London, 1968.

[2] P.J. Mackin and A. A. Smith, "The Aluminium Bronzes," 2nd Edition, Copper Development Association, London, 1966.

[3] Z. Ahmed, "Corrosion Resistance of Cast Al-Bronze Containing Cr and Si Additions," British Journal of Corrosion, Vol. 14, No. 4, 1976, p. 149. http://dx.doi.org/10.1179/000705976798319991

[4] H. Leidheiser, Jr., "The Corrosion of Copper, Tin and their Alloys,” John Wiley \& Sons, New York, 1971.

[5] K. Chandler, "Marine and Offshore Corrosion,” Butterworths, London, 1985.

[6] R. N. Singh, N. Verma and W. R. Singh, "Influence of Minor Additions of La, Ce and Nd on the Mechanical and Corrosion Behavior of Aluminum Bronze in $\mathrm{HNO}_{3}$ Solu- tion,” Corrosion, Vol. 45, No. 3, 1989, pp. 222-229.

http://dx.doi.org/10.5006/1.3577846

[7] F. L. La Que, “Marine Corrosion,” John Wiley \& Sons, New York, 1975.

[8] “Aluminum Bronze Alloy Technical Data,” Copper Development Association, Potters Bar, 1982.

[9] C. Manfredi, S. Simpson and S. R. De Sanchez, "Selection of Copper Base Alloys for Use in Polluted Seawater, Corrosion, Vol. 43, No. 8, 1987, pp. 458-464. http://dx.doi.org/10.5006/1.3583885

[10] B. G. Ateya, E. A. Ashour and S. M. Sayed, "Corrosion of alpha-Aluminum Bronze in Saline Water," Journal of The Electrochemical Society, Vol. 141, No. 1, 1994, pp. 71-78. http://dx.doi.org/10.1149/1.2054712

[11] T. H. Rogers, "Marine Corrosion," George Newnes Pub. Co., London, 1968.

[12] E. A. Ashour, E. A. Abd El Meguid and B. G. Ateya, "Stress Corrosion Behavior of Alpha Aluminum Bronze in Concentrated Alkali Solutions,” Corrosion, Vol. 57, No. 9, 2001, pp. 749-752. http://dx.doi.org/10.5006/1.3280608

[13] B. G. Ateya, E. A. Ashour and S. M. Sayed, "Stress Corrosion Behavior of $\alpha$-Aluminum Bronze in Saline Water," Corrosion, Vol. 50, No. 1, 1994, pp. 20-25. http://dx.doi.org/10.5006/1.3293490

[14] D. T. Hawkins and R. Hultgren, "Metals Handbook, Metallography, Structures and Phase Diagrams," 8th Edition, American Society for Metals, Metals Park, 1973.

[15] M. Schussler, "Minimizing Stress Corrosion Cracking of Cylinder Valves," Corrosion, Vol. 1, No. 3, 1955, pp. 19-21.

[16] Z. I. Tanabe, "Effect of Metal Composition and Heat Treatment on De-Aluminification of Cu-Al Alloys," Corrosion Science, Vol. 4, No. 1, 1964, pp. 413-423. http://dx.doi.org/10.1016/0010-938X(64)90042-3

[17] P. Collins and D.J. Duquette, "Corrosion Fatigue Behavior of a Duplex Aluminum Bronze Alloy,” Corrosion, Vol. 34, No. 4, 1978, pp. 119-124. http://dx.doi.org/10.5006/0010-9312-34.4.119

[18] N. K. Allam, A. A. Nazeer, G. I. Youssef and E. A. Ashour, "Electrochemical and Stress Corrosion Cracking Behavior of $\alpha$-Aluminum Bronze and $\alpha$-Brass in Nitrite Solutions: A Comparative Study," Corrosion, Vol. 69, No. 1, 2013, pp. 77-84. http://dx.doi.org/10.5006/0660

[19] F. Richards, “Chemical Oceanography,” Academic Press, Inc., New York, 1965, p. 611.

[20] J. F. Bates and J. M. Popplewell, "Corrosion of Condenser tube Alloys in Sulfide Contaminated Brine," Corrosion, Vol. 31, No. 8, 1975, pp. 269-275. http://dx.doi.org/10.5006/0010-9312-31.8.269

[21] E. A. Ashour, E. A. Abd El Meguid and B. G. Ateya, "Effects of Thiosulfate on Susceptibility of Type 316 Stainless Steel to Stress Corrosion Cracking in 3.5\% Aqueous Sodium Chloride," Corrosion, Vol. 53, No. 8, 1997, pp. 612-616. http://dx.doi.org/10.5006/1.3290293

[22] N. K. Allam, E. A. Ashour, H. S. Hegazy, B. E. El-Ana- 
douli and B. G. Ateya, "Effects of Benzotriazole on the Corrosion of $\mathrm{Cu}_{10} \mathrm{Ni}$ Alloy in Sulfide-Polluted Salt Water," Corrosion Science, Vol. 47, No. 9, 2005, pp. 2280-2292. http://dx.doi.org/10.1016/j.corsci.2004.09.014

[23] N. K. Allam and E. A. Ashour, "Promoting Effect of Low Concentration of Benzotriazole on the Corrosion of $\mathrm{Cu}_{10} \mathrm{Ni}$ Alloy in Sulfide Polluted Salt Water," Applied Surface Science, Vol. 254, No. 16, 2008, pp. 5007-5011. http://dx.doi.org/10.1016/j.apsusc.2008.01.165

[24] A. El-Domiaty and J. N. Alhajji, “The Susceptibility of 90Cu-10Ni Alloy to Stress Corrosion Cracking in Seawater Polluted by Sulfide Ions,” Journal of Materials Engineering and Performance, Vol. 6, No. 4, 1997, pp. 534544. http://dx.doi.org/10.1007/s11665-997-0126-9

[25] D. Tromans and R. H. Sun, "Anodic Polarization Behavior of Copper in Aqueous Chloride-Benzotriazole Solutions,” Journal of the Electrochemical Society, Vol. 138, No. 11, 1991, pp. 3235-3244. http://dx.doi.org/10.1149/1.2085397

[26] S. Neodo, D. Carugo, J. A. Wharton and K. R. Stokes, "Electrochemical Behaviour of Nickel-Aluminium Bronze in Chloride Media: Influence of $\mathrm{pH}$ and Benzotriazole," Journal of Electroanalytical Chemistry, Vol. 695, 2013, pp. 38-46.

[27] A. Schussler and H. E. Exner, "The Corrosion of NickelAluminium Bronzes in Seawater-I. Protective Layer Formation and the Passivation Mechanism," Corrosion Science, Vol. 34, No. 11, 1993, pp. 1793-1802. http://dx.doi.org/10.1016/0010-938X(93)90017-B

[28] J. R. Macdonald, “Impedance Spectroscopy,” John Wiley and Sons, New York, 1987.

[29] W. A. Badwy, F. M. Al Kharafi and A. S. El Azab, "Electrochemical Behaviour and Corrosion Inhibition of $\mathrm{Al}, \mathrm{Al}-6061$ and $\mathrm{Al}-\mathrm{Cu}$ in Neutral Aqueous Solutions," Corrosion Science, Vol. 41, No. 4, 1999, pp. 709-727. http://dx.doi.org/10.1016/S0010-938X(98)00145-0

[30] W.A. Badwy, M. El Rabiee, N. H. Hilal and H. Nady, "Electrochemical Behavior of $\mathrm{Mg}$ and Some Mg Alloys in Aqueous Solutions of Different pH," Electrochimica Acta, Vol. 55, No. 6, 2010, p. 1880. http://dx.doi.org/10.1016/j.electacta.2009.10.083

[31] S. S. El-Egamy, K. M. Ismail and W. A. Badwy, "Corrosion Behaviour of Copper in Acidic Nitrate Solutions," Corrosion Prevention and Corrosion Control, Vol. 51, No. 3, 2004, pp. 89-97.

[32] F. Bentiss, M. Lagrence, M. Traisnel and J. C. Hornez, "The Corrosion Inhibition of Mild Steel in Acidic Media by a New Triazole Derivative," Corrosion Science, Vol. 41, No. 4, 1999, pp. 789-803. http://dx.doi.org/10.1016/S0010-938X(98)00153-X

[33] C. W. Yan, H. C. Lin and C. N. Cao, "Investigation of Inhibition of 2-Mercaptobenzoxazole for Copper Corrosion,” Electrochimica Acta, Vol. 45, No. 17, 2000, pp. 2815-2821. http://dx.doi.org/10.1016/S0013-4686(00)00385-6

[34] D. Q. Zhang, L. X. Gao and G. D. Zhou, "Inhibition of Copper Corrosion in Aerated Hydrochloric Acid Solution by Heterocyclic Compounds Containing a Mercapto Group," Corrosion Science, Vol. 46, No. 12, 2004, pp. 3031-3040. http://dx.doi.org/10.1016/j.corsci.2004.04.012 